\title{
KUALITAS PRODUK, KUALITAS LAYANAN, DAN KEWAJARAN HARGA BERPENGARUH TERHADAP KEPUASAN PELANGGAN THE OLD CHAMP CAFE
}

\author{
Komang Arya Gustava Kawi Putra ${ }^{1}$ \\ Ni Ketut Seminari ${ }^{2}$ \\ ${ }^{1,2}$ Fakultas Ekonomi dan Bisnis Universitas Udayana, Bali, Indonesia \\ email: aryagustavaputra@gmail.com
}

\begin{abstract}
ABSTRAK
Kepuasan pelanggan merupakan suatu keadaan dimana keinginan, harapan, dan kebutuhan pelanggan terpenuhi. Agar pelanggan merasa puas perusahaan perlu memperhatikan faktorfaktor yang mempengaruhi kepuasan pelanggan. Tujuan penelitian ini adalah untuk mengetahui pengaruh kualitas produk, kualitas layanan, dan kewajaran harga terhadap kepuasan pelanggan. Penelitian ini dilakukan di The Old Champ Cafe Denpasar. Jumlah sampel yang diambil sebanyak 98 responden yang berdomisili di Kota Denpasar, dengan menggunakan metode non probability sampling dengan teknik purposive sampling. Metode pengumpulan data yaitu dengan melakukan survey yang menggunakan kuesioner sebagai instrumen penelitian. Teknik analisis yang digunakan adalah regresi linier berganda. Hasil penelitian menunjukkan bahwa seluruh hipotesis diterima. Kualitas Produk, Kualitas Layanan, dan Kewajaran Harga berpengaruh positif dan signifikan terhadap Kepuasan Pelanggan. Perusahaan diharapkan mampu meningkatkan keunggulan produk mereka dengan menciptakan produk-produk baru yang akan meningkatkan pembelian agar bisa berkembang seiring perkembangan zaman.

Kata kunci: Kualitas Produk, Kualitas Layanan, Kewajaran Harga, Kepuasan Pelanggan.
\end{abstract}

\begin{abstract}
Customer satisfaction is a condition where the desires, hopes and needs of customers are met. So that customers feel satisfied the company needs to pay attention to factors that influence customer satisfaction. The purpose of this study is to determine the effect of product quality, service quality, and price reasonableness on customer satisfaction. This research conducted at The Old Champ Cafe Denpasar with 98 respondents who live in the city of Denpasar, using purposive sampling technique. Data collected using questionnaire. The analysis technique used is multiple linear regression. The results showed that all hypotheses were accepted. Product Quality, Service Quality, and Price Fairness has a positive and significant effect on Customer Satisfaction. The company is expected to be able to increase the superiority of their products by creating new products that will increase purchases so they can develop along with the times. Keywords: Product Quality, Service Quality, Price Fairness, Customer Satisfaction.
\end{abstract}




\section{PENDAHULUAN}

Dunia bisnis modern menuntut persaingan bisnis menjadi sangat ketat pada setiap bidang usaha, baik usaha di pasar domestik maupun di pasar internasional. Di era globalisasi yang semakin ketat akan persaingan ini, setiap perusahaan dituntut agar dapat memberikan dan menjaga kualitas dari produknya apabila tidak ingin tertinggal dengan perusahaan-perusahaan lainnya yang lebih kompetitif (Ayuniah, 2017).

Perkembangan bisnis saat ini, dengan memahami serta memuaskan keinginan dan kebutuhan konsumen melalui penyampaian produk yang berkualitas, layanan yang baik, serta harga yang bersaing, bertujuan agar konsumen tidak beralih ke perusahaan lain sehingga konsumen akan merasa puas dengan perusahaan. Karena para pengusaha atau perusahaan menyadari betapa pentingnya pelanggan bagi kelangsungan usaha mereka (Henriawan, 2015). Perusahaan harus mengerahkan segala upaya dalam memenuhi kebutuhan dan keinginan konsumen agar memperoleh laba yang merupakan tujuan dari setiap perusahan. Perusahaan harus memberikan pemikiran-pemikiran baru, gagasan baru, dan menawarkan produk yang inovatif dalam rangka memuaskan pelanggan. Inovasi dapat mencakup banyak bidang proses bisnis, seperti produk, proses atau layanan, teknologi, organisasi, pemasaran, dan strategi perusahaan. Kepuasan pelanggan dapat memengaruhi niat dan perilaku pembelian kembali. Perusahaan harus mulai memikirkan pentingnya kepuasan pelanggan secara lebih matang, karena kini disadari bahwa pelayanan dan kepuasan pelanggan merupakan aspek vital dalam bertahan didunia bisnis untuk memenangkan persaingan (Sumertana, 2016). Kepuasan konsumen adalah suatu keadaan dimana keinginan, harapan dan kebutuhan pelanggan dipenuhi (Siswanto \& Widjaja, 2017).

Kepuasan pelanggan adalah penilaian pelanggan atas produk ataupun jasa dalam hal menilai apakah produk atau jasa tersebut telah memenuhi kebutuhan dan ekspektasi pelanggan. Kepuasan konsumen juga berkaitan erat dengan kualitas produk, kualitas produk adalah kemampuan sebuah produk dalam memperagakan fungsinya, hal ini termasuk keseluruhan durabilitas, reabilitas, ketepatan, kemudahaan pengoprasian, dan reparasi produk, dan juga reparasi produk lainnya.

Kualitas produk merupakan "proses evaluasi secara keseluruhan kepada pelanggan atas perbaikan kinerja suatu produk, kualitas produk memiliki suatu ketertarikan bagi komsumen dalam mengelola hubungan yang baik antara perusahaan dengan konsumen akan memberikan peluang untuk mengetahui dan memahami apa yang menjadi kebutuhan dan harapan yang ada pada persepsi konsumen. Produk harus memiliki tingkat kualitas tertentu karena produk dibuat untuk memenuhi selera konsumen (Sanjaya \& Ardani, 2018). Kualitas suatu produk menjelaskan kemampuan suatu produk atau merek, apakah sudah sesuai dengan manfaat dan fungsinya

Bilamana suatu produk atau merek didapati kurang sesuai dengan kualitas yang diinginkan, maka pelanggan akan merasa kecewa dan yang paling merugikan lagi akan berpaling ke produk atau merek lain yang sejenis. Oleh sebab itu, suatu produk yang berkualitas harus dapat meningkatkan kepuasan pelanggan. Kualitas mencerminkan semua dimensi penawaran produk yang menghasilkan manfaat (benefits) bagi pelanggan. Meningkatkan kualitas suatu produk merupakan salah 
satu strategi perusahaan dalam menarik perhatian para pelanggan. Konsumen akan menggunakan penilaian mereka dalam menentukan dan membuat keputusan, terutama saat membeli produk yang berkualitas (Ackaradejruangsri, 2015). Hal ini berarti konsumen akan lebih memilih produk yang kualitasnya lebih baik dibanding yang kualitasnya lebih rendah. Berdasarkan pemaparan tersebut bahwa kualitas produk berpengaruh terhadap kepuasan pelanggan.

Menurut Kristiana \& Kastawan (2019) layanan adalah setiap tindakan atau kegiatan yang dapat ditawarkan oleh suatu pihak kepada pihak lain yang pada dasarnya tidak berwujud dan tidak mengakibatkan kepemilikan apapun. Layanan merupakan suatu bentuk sistem, prosedur atau metode tertentu yang diberikan kepada orang lain. Ketika layanan atau jasa yang didapat atau diterima sesuai dengan apa yang diharapkan, maka kualitas layanan atau jasa dipersepsikan memuaskan dan baik. Kualitas layanan memiliki hubungan yang signifikan terhadap kepuasan pelanggan. Kualitas layanan mampumemberikan suatu dorongan kepada pelanggan untuk menjalin ikatan atauhubungan yang kuat dengan perusahaan. Semakin berkualitas layanan yang diberikan oleh perusahaan, kepuasan yang dirasakan oleh pelanggan akan semakin tinggi (Panjaitan \& Yuliati, 2016). Menurut Suariedewi \& Sulistyawati (2016) memberikan kualitas layanan yang baik akan berdampak pada perceived value pelanggan yang semakin tinggi dan akan berdampak pada kepuasan pelanggan

Berdasarkan "sudut pandang konsumen, harga sering kali menjadi daya tarik konsumen untuk membeli atau mengkonsumsi suatu produk. Harga merupakan peran strategik dalam pemasaran. Harga merupakan satuan moneter atau ukuran lainnya (termasuk barang dan jasa lainnya) yang ditukarkan agar memperoleh hak kepemilikan atau penggunaan suatu barang atau jasa. Harga merupakan salah satu cara untuk mendorong minat konsumen untuk melakukan pembelian. Perbedaan layanan yang dirasakan dapat menimbulkan kewajaran harga di benak konsumen, kewajaran harga yang dirasakan akan menimbulkan niat beli yang akan membentuk keputusan membeli.

Bagi konsumen, harga sangat mempengaruhi kualitas barang dan keputusan pembelian karena banyak orang menganggap bahwa barang yang memiliki kualitas baik, maka untuk memperolehnya pun tidak sedikit yang kita korbankan karena harganya pasti sangat tinggi (Putra \& Ekawati, 2017). Aktivitas inovasi yang kreatif baik itu inovasi proses maupun inovasi produk akan meningkatkan kemampuan perusahaan menciptakan produk yang berkualitas selanjutnya diharapkan akan meningkatkan keunggulan bersaing perusahaan yang pada akhirnya berdampak pada kinerja perusahaan (Ekawati, 2016). Menurut Oosthuizen \& Spowart (2015) "harga dan kualitas memiliki pengaruh yang tinggi terhadap kepuasan pelanggan, masih ada sedikit bukti empiris mengeksplorasi hubungan ini, hal ini merupakan salah satu faktor yang kurang diperhatikan oleh perusahaan, sehingga konsumen akan berfikir lagi untuk menggunakan produk tersebut dan akan merasa tidak puas setelah membeli atau menggunakan barang atau jasa tersebut." 
Tabel 1.

Menu pada The Old Champ Cafe

\begin{tabular}{llll}
\hline Menu & Harga & Menu & Harga \\
\hline Appetizer & & Main Course & \\
Veggie Lumpia & $\mathrm{Rp} 19.000$ & Chicken Cordon Bleu & $\mathrm{Rp} 35.000$ \\
Crispy Tortilla Chip & $\mathrm{Rp} 25.000$ & BBQ Pork Ribs & $\mathrm{Rp} 40.000$ \\
Chicken Salad & $\mathrm{Rp} 24.000$ & Chicken Parmigiana & $\mathrm{Rp} 40.000$ \\
Tuna Salad & $\mathrm{Rp} 24.000$ & Bo Lu Lac & $\mathrm{Rp} 42.000$ \\
Tom Yum Kung & $\mathrm{Rp} 25.000$ & & \\
Drinks & & Pizza Corner & \\
Fresh juice & $\mathrm{Rp} 20.000$ & The Old Champ Special Pizza & $\mathrm{Rp} 50.000$ \\
Lady Rose & $\mathrm{Rp} 22.000$ & Margarita Pizza & $\mathrm{Rp} 30.000$ \\
Hakunamatata & $\mathrm{Rp} 25.000$ & Chicken Ham Pizza & $\mathrm{Rp} 35.000$ \\
Strawberry Junkie & $\mathrm{Rp} 22.000$ & Seafood Pizza & $\mathrm{Rp} 50.000$ \\
Dessert & & & \\
Mini Pancake & $\mathrm{Rp} 20.000$ & & \\
French Toast & $\mathrm{Rp} 15.000$ & & \\
Banana Split & $\mathrm{Rp} 25.000$ & & \\
Sumber: The Old Champ Cafe, 2020 & &
\end{tabular}

Banyak usaha yang berkembang dengan sangat pesat, salah satunya bisnis di bidang kuliner yang bermunculan mengakibatkan peningkatan jumlah usaha yang bersifat sejenis menyebabkan persaingan yang semakin ketat. Maka untuk menghadapi situasi dan keadaan yang demikian, pengusaha harus mampu serta cepat dan tanggap dalam mengambil keputusan agar usaha yang didirikannya dapat berkembang dengan baik (Gunawan \& Chandra, 2018). Jumlah rumah makan yang berada di kota Denpasar pada tahun 2019 yaitu sebanyak 582 rumah makan. Bisnis kuliner di Bali kian mengalami perkembangan yang signifikan. Hal itu dikarenakan semakin menjamurnya usaha kuliner di sentra kepariwisataan, meningkatnya bisnis kuliner dipicu karena kebutuhan masyarakat di kota-kota besar. Jumlah proyeksi penduduk di Kota Denpasar tahun 2020 sebanyak 962.90 jiwa yang terdiri dari 491.50 laki-laki dan 471.40 perempuan.

The Old Champ Cafe merupakan bisnis kuliner yang berdiri sejak tahun 2015 yang berkembang pesat hingga sekarang yang berlokasi di Jalan Merdeka No. 10B, Renon, Denpasar, Bali. Produk yang ditawarkan kompetitif dengan pesaingpesaingnya, desain yang menarik dan ada beragam menu yang membuat para konsumen tertarik untuk mengunjunginya. Berdasarkan laman web The Old Champ Cafe dari 300 ulasan, terdapat 115 ulasan yang mengkritik dari segi layanan dan kualitas produk. Berdasarkan dari hasil pra survei yang telah dilakukan terhadap 15 responden dapat dijelaskan bahwa dari 15 responden yang disurvei, mengenai tingkat kepuasan produk, terdapat 12 menjawab setuju dan 3 menjawab tidak setuju. Tentunya hal ini menandakan bahwa responden merasa puas terhadap produk yang ditawarkan The Old Champ Cafe. 
Tabel 2.

Pra Survei Konsumen The Old Champ Cafe

\begin{tabular}{|c|c|c|c|}
\hline Variabel & Pernyataan & Jawaban & Responden \\
\hline Kualitas produk & $\begin{array}{l}\text { Saya merasakan kepuasan terhadap } \\
\text { kualitas produk The Old Champ Cafe }\end{array}$ & $\begin{array}{l}1=\mathrm{SS} \\
5=\mathrm{S} \\
6=\mathrm{CS} \\
3=\mathrm{TS} \\
0=\mathrm{STS}\end{array}$ & 15 \\
\hline Kualitas layanan & $\begin{array}{l}\text { Saya merasakan kenyamanan pada } \\
\text { service yang diberikan pada saat } \\
\text { pembelian di The Old Champ Cafe }\end{array}$ & $\begin{array}{l}2=\mathrm{SS} \\
5=\mathrm{S} \\
4=\mathrm{CS} \\
3=\mathrm{TS} \\
1=\mathrm{STS}\end{array}$ & 15 \\
\hline Kewajaran harga & $\begin{array}{l}\text { Harga yang ditawarkan sesuai dengan } \\
\text { kualitas produk di The Old Champ } \\
\text { Cafe }\end{array}$ & $\begin{array}{l}3=\mathrm{SS} \\
3=\mathrm{S} \\
4=\mathrm{CS} \\
4=\mathrm{TS} \\
1=\mathrm{STS}\end{array}$ & 15 \\
\hline Kualitas layanan & $\begin{array}{l}\text { Karyawan pada The Old Champ Cafe } \\
\text { bersikap responsif terhadap } \\
\text { konsumen }\end{array}$ & $\begin{array}{l}3=\mathrm{SS} \\
6=\mathrm{S} \\
2=\mathrm{CS} \\
4=\mathrm{TS} \\
0=\mathrm{STS}\end{array}$ & 15 \\
\hline
\end{tabular}

Sumber : Survei pendahuluan, 2020

Tabel 2. terkait dengan kenyamana service pada The Old Champ Cafe 11 menjawab setuju dan 4 menjawab tidak setuju, jadi bisa dikatakan setuju terhadap kenyaman service The Old Champ Cafe. Berdasarkan harga yang ditawarkan sesuai dengan produk The Old Champ Cafe, 10 menjawab setuju dan 5 menjawab tidak setuju dengan harga yang ditawarkan sesuai dengan kualitas produk, jadi bisa dikatakan setuju terhadap harga yang ditawarkan. Sesuai dengan kualitas layanan 11 menjawab setuju dan 4 menjawab tidak setuju dengan layanan yang responsif terhadap konsumen. Berdasarkan data diatas sebagian besar konsumen merasakan kepuasan karena adanya pengaruh positif terhadap produk dan layanan.

Terkait dengan kenyamana service pada The Old Champ Cafe 11 menjawab setuju dan 4 menjawab tidak setuju, jadi bisa dikatakan setuju terhadap kenyaman service The Old Champ Cafe. Berdasarkan harga yang ditawarkan sesuai dengan produk The Old Champ Cafe, 10 menjawab setuju dan 5 menjawab tidak setuju dengan harga yang ditawarkan sesuai dengan kualitas produk, jadi bisa dikatakan setuju terhadap harga yang ditawarkan. Sesuai dengan kualitas layanan 11 menjawab setuju dan 4 menjawab tidak setuju dengan layanan yang responsif terhadap konsumen. Berdasarkan data diatas sebagian besar konsumen merasakan kepuasan karena adanya pengaruh positif terhadap produk dan layanan. 
Berdasarkan latar belakang dan research gap yang ditemukan, maka masih diperlukannya penelitian mengenai pengaruh kualitas produk, kualitas layanan, dan kewajaran harga terhadap kepuasan pelanggan dengan mengambil studi pada pelanggan The Old Champ Cafe di Kota Denpasar. Tujuan dari penelitian ini adalah untuk mengetahui pengaruh kualitas produk terhadap kepuasan pelanggan pada The Old Champ Cafe di Kota Denpasar, mengetahui pengaruh kewajaran harga terhadap kepuasan pelanggan pada The Old Champ Cafe di Kota Denpasar dan mengetahui pengaruh lokasi terhadap kepuasan pelanggan pada The Old Champ Cafe di Kota Denpasar.

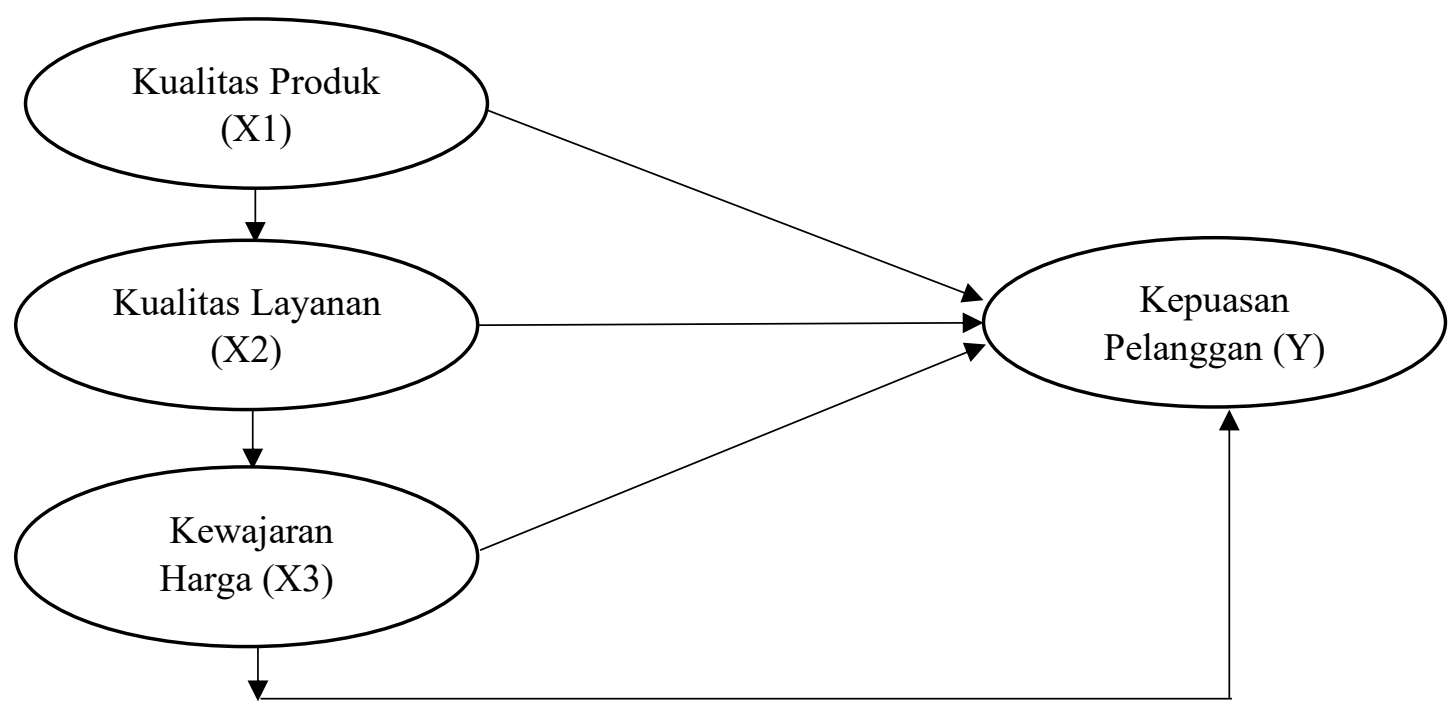

Gambar 1. Kerangka Konseptual

Dalam penelitian Hoe \& Mansori (2018) bahwa kualitas produk berpengaruh signifikan terhadap kepuasan pelanggan. Ismail \& Yunan (2016) menemukan bahwa peningkatan kualitas produk yang kompetitif dapat meningkatkan kepuasan pelanggan. Kualitas produk memiliki pengaruh positif terhadap kepuasan pelanggan dikemukakan pada penelitian yang dilakukan oleh Nuridin (2018). Wijaya \& Nurcaya (2017) menemukan terdapat pengaruh positif signifikan kualitas produk terhadap kepuasan pelanggan. Penelitian Alfin (2016) menyatakan bahwa adanya pengaruh signifikan antara kualitas produk terhadap kepuasan pelanggan. Razak \& Boge (2016) menyatakan bahwa kualitas produk berpengaruh positif terhadap kepuasan pelanggan. Kurnia (2016) dalam penelitiannya juga menunjukkan bahwa kualitas produk memiliki pengaruh positif terhadap kepuasan konsumen. Berdasarkan hasil penelitian yang telah dikemukakan, maka pada penelitian ini hipotesis yang dapat ditarik sebagai berikut.

$\mathrm{H}_{1}$ : Kualitas produk berpengaruh positif dan signifikan terhadap kepuasan konsumen

Kualitas layanan dari perusahaan memiliki pengaruh positif terhadap kepuasan pelanggan (Gong \& Yi, 2018). Menurut Niaam \& Adhimmum (2016) didapatkan hasil bahwa kualitas layanan berpengaruh positif dan signifikan 
terhadap kepuasan pelanggan. Menurut penelitian yang telah dilakukan oleh Minh et al. (2015) memperlihatkan kualitas layanan memiliki pengaruh yang positif dan signifikan dengan kepuasan pelanggan. Menurut Danish et al. (2018) mengatakan bahwa kualitas layanan memiliki pengaruh positif dan signifikan terhadap kepuasan pelanggan

Teori mengenai pengaruh kualitas layanan terhadap kepuasan ini diperkuat oleh beberapa studi empiris yang dilakukan oleh para peneliti sebelumnya, yang dijadikan referensi dalam penelitian ini yaitu Sutrisno \& Andajani (2019) yang berpendapat sama bahwa kualitas layanan berpengaruh positif dan signifikan terhadap kepuasan pelanggan. Penelitian yang juga dilakukan oleh Nurmalasari \& Jokom (2016) mengenai kualitas layanan, hasil penelitian tersebut menunjukan kepuasan pelanggan berpengaruh positif dan signifikan. Secara parsial kualitas layanan yamg terdiri dari 5 dimensi yaitu bukti fisik, kehandalan, daya tangkap, jaminan dan empati berpengaruh positif dan signifikan terhadap kepuasan konsumen. Berdasarkan hasil penelitian yang telah dikemukakan, maka pada penelitian ini hipotesis yang dapat ditarik sebagai berikut.

$\mathrm{H}_{2}$ : Kualitas layanan berpengaruh positif dan signifikan terhadap kepuasan konsumen

Penelitian yang dilakukan oleh Surip et al. (2017), menyatakan bahwa variabel harga berpengaruh signifikan terhadap kepuasan konsumen. Penelitian Ismail \& Yunan (2016) menemukan bahwa harga yang kompetitif dapat meningkatkan kepuasan pelanggan, hal ini juga didukung oleh studi dari Ehsani (2015), mereka mengatakan bahwa harga dapat meningkatkan kepuasan pelanggan. Wijaya \& Nurcaya (2017) menyatakan bahwa dalam penelitiannya harga memiliki pengaruh yang positif dan signifikan terhadap kepuasan pelanggan, namun berbeda dengan penelitian yang telah dilakukan Mahmud et al. (2015) menunjukkan hasil negatif dan tidak signifikan Antara variabel harga terhadap kepuasan konsumen. Sutrisno \& Andajani (2019) yang berpendapat sama bahwa kualitas pelayanan berpengaruh positif dan signifikan terhadap kepuasan pelanggan. kewajaran harga (price fairness) dan kepuasan pelanggan (customer satisfaction), dalam penelitiannya menunjukan kewajaran harga dapat memengaruhi kepuasan pelanggan.

Penelitian sebelumnya yang dilakukan oleh Kao (2007) menyatakan bahwa dalam institusi akademis, kualitas pelayanan memiliki pengaruh lebih besar terhadap kepuasan pelajar dibandingkan kewajaran harga. Rahyuda \& Atmaja (2011) dalam hasil penelitiannya menemukan hasil yang berbeda, dimana kewajaran harga tidak beperngaruh terhadap kepuasan pelanggan.Hasil yang berbeda didapatkan oleh Nguyen (2015) yang dalam penelitiannya mendapatkan bahwa service quality berpengaruh positif dan signifikan terhadap kepuasan mahasiswa, begitu pula dengan kewajaran harga yang berpengaruh positif dan signifikan terhadap kepuasan mahasiswa dimana apabila semakin mahasiswa beranggapan bahwa pendidikan yang diterima sesuai dengan harga yang dibayarkan maka kepuasan mahasiswa akan semakin meningkat. Berdasarkan hasil penelitian yang telah dikemukakan, maka pada penelitian ini hipotesis yang dapat ditarik sebagai berikut. 
$\mathrm{H}_{3}$ : Kewajaran harga berpengaruh positif dan signifikan terhadap kepuasan konsumen

\section{METODE PENELITIAN}

Penelitian ini apabila dilihat dari variabel serta keterkaitan yang akan diteliti, maka dapat dikategorikan sebagai penelitian asosiatif yang bertujuan untuk mengetahui hubungan antara dua variabel atau lebih. Hubungan antara dua variabel atau lebih dalam penelitian ini membahas mengenai pengaruh kualitas produk terhadap kepuasan konsumen, pengaruh kualitas layanan terhadap kepuasan konsumen, serta pengaruh kewajaran harga terhadap kepuasan konsumen.

Penelitian ini dilakukan di Restoran The Old Champ Cafe yang beralamat di Jalan Merdeka Renon, Denpasar. Pemilihan lokasi ini, karena belum ada yang melakukan penelitian pada The Old Champ Cafe, terdapat beberapa masalah pada restoran ini seperti keluhan yang disampaikan kepada pelanggan restoran sehingga menarik untuk diteliti, serta ingin memberikan kontribusi positif bagi restoran yang berhubungan dengan kepuasan pelanggan. Lokasi dari penelitian ini yaitu berada di Kota Denpasar. Lokasi ini dipilih karena menjamurnya resto-resto di sepanjang jalan yang ada di Denpasar, menunjukkan bahwa kuliner di Bali memiliki penggemar tersendiri dan mendapat tempat di hati masyarakat Bali dan wisatawan.

Obyek penelitian ini yaitu kepuasan pelangan yang dipengaruhi oleh kualitas produk, kualitas layanan, dan kewajaran harga pada The Old Champ Cafe. Variabel bebas pada penelitian ini adalah kualitas produk, kualitas layanan, dan kewajaran harga. Variabel terikat yang digunakan penelitian ini adalah kepuasan konsumen.

Data kuantitatif dalam penelitian ini berupa pendapat responden terhadap pernyataan yang meliputi variabel kualitas produk, kualitas layanan, dan kewajaran harga. Data kualitatif dalam penelitian ini adalah data kualitatif yang diangkakan dengan metode skoring. Data primer yang digunakan dalam penelitian ini diperoleh dari jawaban responden terhadap pernyataan kuisioner yang dikumpulkan dari konsumen The Old Champ Cafe yang berdomisili di Kota Denpasar. Data sekunder yang digunakan dalam penelitian ini adalah data yang diolah oleh peneliti yang didapat dari pihak ketiga yang berbentuk informasi dan dokumentasi yang diperoleh dari buku referensi, internet, dan penelitian-penelitian sebelumnya

Dalam penelitian ini, populasi yang digunakan yaitu konsumen yang pernah membeli produk The Old Champ Cafe yang berdomisili di Kota Denpasar. Jumlah indikator dalam penelitian ini berjumlah 14 indikator, dengan demikian ukuran sampel yang diambil adalah 7 X $14=98$ sampel. Pada penelitian ini dapat diambil responden sebanyak 98 orang yang sudah dapat dikatakan cukup untuk membuktikan hasil penelitian ini. Teknik pengambilan sampling dalam penelitian ini adalah menggunakan non probability sampling yaitu purposive sampling. Kriteria penentuan sampel dalam penelitian ini yaitu: Responden berdomisili di Kota Denpasar, Minimal pendidikan responden yaitu SMA karena responden yang memiliki tingkat pendidikan minimal SMA atau sederajat diasumsikan dapat memahami pertanyaan dan mengisi kuesioner dengan baik, Responden yang pernah melakukan pembelian terhadap produk The old Champ Cafe (minimal 2 kali) dan Responden yang pernah melakukan pembelian di cafe/rumah makan lainnya, 
diasumsikan agar bisa menjawab kuesioner dengan baik. Data penelitian ini dikumpulkan dengan instrument berupa kuesioner yang disebarkan kepada responden yang berdomisili di Kota Denpasar.

\section{HASIL DAN PEMBAHASAN}

The Old Champ Cafe merupakan salah satu bisnis kuliner yang berdiri sejak tahun 2015 yang berkembang pesat hingga sekarang yang berlokasi di Jalan Merdeka no. 10B, Renon, Denpasar, Bali. The Old Champ Cafe didirikan oleh Putu Agus Bila Setiawan dengan Kadek Yuki Kobayashi pada tanggal 9 Mei 2015, dimana konsep dari The Old Champ Cafe yaitu American Vintage, produk yang ditawarkan kompetitif dengan pesaing-pesaingnya dan ada beberapa menu yang berbeda dari yang lainnya, desain yang menarik dan ada beragam menu yang membuat para konsumen tertarik untuk mengunjunginya. The Old Champ Cafe menawarkan suasana Old Vibe dan menyediakan beberapa menu makanan Italia, Western, Jepang, Vietnam, Thailand dan Indonesia. Suasana dinding yang agak gelap dengan gemerlap lampu dan beberapa lukisan membuat tempat ini terkesan elegan. Makanan memiliki porsi yang cukup besar dengan harga yang tidak terlalu mahal.

Tabel 3.

Daftar Menu The Old Champ Cafe

\begin{tabular}{llll}
\hline \multicolumn{1}{c}{ MENU } & HARGA & \multicolumn{1}{c}{ MENU } & HARGA \\
\hline $\begin{array}{l}\text { Appetizer } \\
\text { Veggie Lumpia }\end{array}$ & Rp19.000 & $\begin{array}{l}\text { Main Course } \\
\text { Chicken Cordon Bleu }\end{array}$ & Rp35.000 \\
Crispy Tortilla Chip & Rp25.000 & $\begin{array}{l}\text { BBQ Pork Ribs } \\
\text { Chicken Parmigiana }\end{array}$ & Rp40.000 \\
Chicken Salad & Rp24.000 & Ro 40.000 \\
Tuna Salad & Rp24.000 & Bo Lu Lac & Rp42.000 \\
Tom Yum Kung & Rp25.000 & Pizza Corner & \\
Drinks & & The Old Champ Special Pizza & Rp50.000 \\
Fresh juice & Rp20.000 & Rp30.000 \\
Lady Rose & Rp22.000 & Margarita Pizza & Rp35.000 \\
Hakunamatata & Rp25.000 & Chicken Ham Pizza & Rp50.000 \\
Strawberry Junkie & Rp22.000 & Seafood Pizza & \\
Dessert & & & \\
Mini Pancake & Rp20.000 & & \\
French Toast & Rp15.000 & & \\
Banana Split & Rp25.000 & & \\
\hline Sumber: The Old Champ Cafe, 2020 & &
\end{tabular}


Tabel 4.

Karakteristik Responden Penelitian

\begin{tabular}{|c|c|c|c|c|}
\hline No & Karakteristik & Klarifikasi & $\begin{array}{l}\text { Jumlah } \\
\text { (orang) }\end{array}$ & $\begin{array}{c}\text { Persentase } \\
(\%)\end{array}$ \\
\hline \multirow{3}{*}{1} & \multirow{2}{*}{ Jenis kelamin } & Laki - laki & 36 & 36,7 \\
\hline & & Perempuan & 62 & 63,3 \\
\hline & \multicolumn{2}{|c|}{ Jumlah } & 98 & 100 \\
\hline \multirow{4}{*}{2} & \multirow{3}{*}{ Usia } & 17-20 tahun & 8 & 8,2 \\
\hline & & 21- 30 tahun & 87 & 88,8 \\
\hline & & $>30$ tahun & 3 & 3 \\
\hline & \multicolumn{2}{|c|}{ Jumlah } & 98 & 100 \\
\hline \multirow{4}{*}{3} & \multirow{3}{*}{ Pendidikan terakhir } & SMA/Sederajat & 23 & 23,5 \\
\hline & & Diploma/S1 & 72 & 73,5 \\
\hline & & Pasca Sarjana & 3 & 3 \\
\hline & \multicolumn{2}{|c|}{ Jumlah } & 98 & 100 \\
\hline
\end{tabular}

Sumber: Data primer diolah, 2020

Jumlah responden perempuan yang melakukan pembelian di The Old Champ Cafe cenderung lebih banyak yaitu sebanyak 63,3 persen dari seluruh responden, sedangkan jumlah responden laki-laki yang melakukan pembelian di The Old Champ Cafe adalah sebanyak 36,7 persen dari seluruh responden. Secara umum dapat disimpulkan bahwa responden pada penelitian ini lebih banyak adalah perempuan.

Pada karakteristik berdasarkan usia didapatkan hasil bahwa responden yang paling banyak jumlahnya adalah responden dengan rentang usia 21-30 tahun yang berjumlah 88,8 persen dari seluruh responden yang tinggal di kota Denpasar, dan sisanya berusia 17-20 tahun sebanyak 8,2 persen $>30$ tahun sebanyak 3 persen dari keseluruhan responden. Data ini membuktikan bahwa secara umum responden dalam penelitian ini berada pada rentang usia 21-30 tahun adalah yang paling aktif dalam melakukan pembelian di The Old Champ Cafe.

Pada karakteristik berdasarkan pendidikan terakhir di dapatkan hasil bahwa responden yang paling banyak adalah responden dengan pendidikan terakhir sebagai Diploma/S1 dengan jumlah sebanyak 73,5 persen dari seluruh responden, sisanya adalah SMA/Sederajat sebanyak 23,5 persen dan Pasca Sarjana sebanyak 3 persen. Data ini menunjukkan bahwa responden yang memiliki pendidikan terakhir Diploma/S1 lebih dominan untuk melakukan pembelian di The Old Champ cafe.

Seluruh instrumen penelitian dari masing-masing indikator mempunyai nilai koefisien korelasi yang lebih besar dari 0,3. Sehingga seluruh indikator yang digunakan pada instrumen penelitian dengan menggunakan 30 sampel dinyatakan valid. 
Tabel 5.

Hasil Uji Validitas

\begin{tabular}{|c|c|c|c|c|}
\hline No & Variabel & Indikator & $\begin{array}{l}\text { Koefisien } \\
\text { Korelasi }\end{array}$ & $\begin{array}{l}\text { Koefisien } \\
\text { Batas }\end{array}$ \\
\hline 1 & Kualitas Produk & $\begin{array}{l}X_{1.1} \\
\mathrm{X}_{1.2} \\
\mathrm{X}_{1.3} \\
X_{1.4}\end{array}$ & $\begin{array}{l}0,939 \\
0,868 \\
0,874 \\
0,887\end{array}$ & $\begin{array}{l}0,3 \\
0,3 \\
0,3 \\
0,3\end{array}$ \\
\hline 2 & Kualitas layanan & $\begin{array}{l}\mathrm{X}_{2.1} \\
\mathrm{X}_{2.2} \\
\mathrm{X}_{2.3} \\
\mathrm{X}_{2.4}\end{array}$ & $\begin{array}{l}0,912 \\
0,924 \\
0,847 \\
0,839\end{array}$ & $\begin{array}{l}0,3 \\
0,3 \\
0,3 \\
0,3\end{array}$ \\
\hline 3 & Kewajaran Harga & $\begin{array}{l}X_{3.1} \\
X_{3.2} \\
X_{3.3}\end{array}$ & $\begin{array}{l}0,834 \\
0,728 \\
0,918\end{array}$ & $\begin{array}{l}0,3 \\
0,3 \\
0,3\end{array}$ \\
\hline 4 & Kepuasan Konsumen & $\begin{array}{l}Y_{1.1} \\
Y_{1.2} \\
Y_{1.3}\end{array}$ & $\begin{array}{l}0,835 \\
0,849 \\
0,911\end{array}$ & $\begin{array}{l}0,3 \\
0,3 \\
0,3\end{array}$ \\
\hline
\end{tabular}

Sumber: Data primer diolah, 2020

Tabel 6.

Uji Reliabilitas Instrumen

\begin{tabular}{clc}
\hline No & Variabel & Cronbach's Alpha \\
\hline 1 & Kualitas produk (X1) & 0,912 \\
2 & Kualitas Layanan (X2) & 0,899 \\
3 & Kewajaran Harga (X3) & 0,772 \\
4 & Kepuasan Pelanggan (Y) & 0,830 \\
\hline
\end{tabular}

Sumber: Data primer diolah, 2020

Semua variabel pada penelitian ini dapat di katakan Reliabel dan telah memenuhi syarat konsistensi maupun keandalan data. Hasil uji reliabilitas menunjukan bahwa masing-masing nilai Cronbach's Alpha lebih besar dari 0,60 sehingga dapat digunakan untuk melakukan penelitian.

Keempat pernyataan mengenai kualitas produk pada The Old Champ. Responden dengan jawaban paling baik ada pada pernyataan produk The Old Champ Cafe berbeda dengan tempat makan lainnya dengan nilai rata-rata 4,26 ada pada kreteria sangat baik, dimana responden tahu akan produk yang ada pada The Old Champ Cafe. Nilai rata-rata terendah yaitu terhadap pernyataan adanya fitur tambahan dalam setiap produk The Old Champ Cafe dengan nilai rata-rata 4,05 dan masuk pada kreteria baik, dimana responden mengakui bahwa adanya fitur tambahan dalam setiap produk The Old Champ Cafe. Nilai rata-rata keseluruhan variabel kualitas produk yaitu sebesar 4,16 dimana menyatakan bahwa responden memiliki persepsi yang baik akan kualitas produk The Old Champ Cafe. 
Tabel 7.

Penilaian Responden Terhadap Indikator Variabel Kualitas Produk

\begin{tabular}{|c|c|c|c|c|c|c|c|c|}
\hline \multirow{2}{*}{ No } & \multirow{2}{*}{ Pernyataan } & \multicolumn{5}{|c|}{ Skor Jawaban } & \multirow{2}{*}{$\begin{array}{l}\text { Rata- } \\
\text { Rata }\end{array}$} & \multirow{2}{*}{ Ket. } \\
\hline & & 1 & 2 & 3 & 4 & 5 & & \\
\hline 1 & $\begin{array}{l}\text { Saya merasakan produk } \\
\text { yang ditawarkan The Old } \\
\text { Champ Cafe sesuai } \\
\text { dengan apa yang saya } \\
\text { harapkan. }\end{array}$ & 0 & 2 & 11 & 45 & 40 & 4,26 & $\begin{array}{c}\text { Sangat } \\
\text { Baik }\end{array}$ \\
\hline 2 & $\begin{array}{l}\text { Saya merasa adanya fitur } \\
\text { tambahan dalam setiap } \\
\text { produk The Old Champ } \\
\text { Cafe. }\end{array}$ & 0 & 3 & 19 & 46 & 30 & 4,05 & Baik \\
\hline 3 & $\begin{array}{l}\text { Saya merasakan daya } \\
\text { tarik pada setiap produk } \\
\text { yang disajikan The Old } \\
\text { Champ Cafe. }\end{array}$ & 0 & 2 & 14 & 44 & 38 & 4,20 & $\begin{array}{c}\text { Sangat } \\
\text { Baik }\end{array}$ \\
\hline 4 & $\begin{array}{l}\text { Saya merasa seluruh } \\
\text { produk The Old Champ } \\
\text { Cafe memiliki citra yang } \\
\text { baik. } \quad \text { Skor Rata-Rata }\end{array}$ & 0 & 3 & 18 & 42 & 35 & 4,11 & Baik \\
\hline
\end{tabular}

Sumber: Data primer diolah, 2020

Tabel 8.

Penilaian Responden Terhadap Indikator Variabel Kualitas Layanan

\begin{tabular}{|c|c|c|c|c|c|c|c|c|}
\hline \multirow{2}{*}{ No } & \multirow{2}{*}{ Pernyataan } & \multicolumn{5}{|c|}{ Skor Jawaban } & \multirow{2}{*}{$\begin{array}{l}\text { Rata- } \\
\text { Rata }\end{array}$} & \multirow{2}{*}{ Ket. } \\
\hline & & 1 & 2 & 3 & 4 & 5 & & \\
\hline \multirow[t]{2}{*}{1} & Saya merasa The Old & & & & & & & \\
\hline & $\begin{array}{l}\text { Champ Cafe memiliki } \\
\text { suasana cafe yang } \\
\text { menarik. }\end{array}$ & 0 & 1 & 10 & 45 & 42 & 4,31 & $\begin{array}{c}\text { Sangat } \\
\text { Baik }\end{array}$ \\
\hline \multirow[t]{2}{*}{2} & Saya merasa pelayanan & & & & & & & \\
\hline & $\begin{array}{l}\text { The Old Champ Cafe } \\
\text { sangat responsif. }\end{array}$ & 0 & 3 & 29 & 42 & 24 & 3,89 & Baik \\
\hline 3 & $\begin{array}{l}\text { Saya merasa percaya } \\
\text { terhadap The Old Cahamp } \\
\text { Cafe.. }\end{array}$ & 0 & 1 & 19 & 52 & 26 & 4,05 & Baik \\
\hline \multirow[t]{2}{*}{4} & $\begin{array}{l}\text { Saya merasa diperhatikan } \\
\text { ketika melakukan } \\
\text { pembelian pada The Old } \\
\text { Champ Cafe. }\end{array}$ & 0 & 5 & 28 & 38 & 27 & 3,89 & Baik \\
\hline & Skor Rata-Rata V & aria & $\tau$ & Laya & & & 4,03 & Baik \\
\hline
\end{tabular}

Sumber: Data primer diolah, 2020

Penilaian responden terhadap setiap indikator dari variabel kualitas layanan, dimana pernyataan mengenai suasana cafe yang menarik memiliki nilai rata-rata tertinggi sebesar 4,31 yang masuk kedalam kriteria sangat baik, hal ini berarti bahwa responden menganggap suasana dari The Old Champ Cafe adalah sangat baik dalam benak responden. Skor rata-rata terendah yaitu sebesar 3,89 yang termasuk dalam kriteria baik ditunjukkan pada indikator dengan pernyataan bahwa 
pelayanan The Old Champ Cafe sangat responsif hal ini berarti responden mengakui bahwa pelayanan yang diberika The Old Champ Cafe yaitu pelayanan yang responsif. Jumlah skor rata-rata indikator secara keseluruhan sebesar 4,03 yang termasuk dalam kriteria baik

Tabel 9.

Penilaian Responden Terhadap Indikator Variabel Kewajaran Harga

\begin{tabular}{|c|c|c|c|c|c|c|c|c|}
\hline \multirow{2}{*}{ No } & \multirow{2}{*}{ Pernyataan } & \multicolumn{5}{|c|}{ Skor Jawaban } & \multirow{2}{*}{$\begin{array}{l}\text { Rata- } \\
\text { Rata }\end{array}$} & \multirow{2}{*}{ Ket. } \\
\hline & & 1 & 2 & 3 & 4 & 5 & & \\
\hline 1 & $\begin{array}{l}\text { Saya merasa harga yang } \\
\text { ditawarkan The Old } \\
\text { Champ Cafe sesuai } \\
\text { dengan kualitas layanan } \\
\text { yang diberikan. }\end{array}$ & 0 & 6 & 25 & 44 & 23 & 3,86 & Baik \\
\hline 2 & $\begin{array}{l}\text { Saya merasa harga dari } \\
\text { The Old Champ Cafe } \\
\text { sesuai dengan } \\
\text { kemampuan saya. }\end{array}$ & 0 & 4 & 30 & 39 & 25 & 3,87 & Baik \\
\hline 3 & $\begin{array}{l}\text { Harga yang ditawarkan } \\
\text { The Old Champ Cafe } \\
\text { kompetitif dengan } \\
\text { kompetitor lainnya. } \\
\text { Skor Rata-Rata }\end{array}$ & 0 & 10 & 13 & 43 & 32 & 3,99 & Baik \\
\hline
\end{tabular}

Sumber: Data primer diolah, 2020

Penilaian responden terhadap setiap indikator dari variabel kewajaran harga, dimana pernyataan mengenai harga yang ditawarkan The Old Champ Cafe kompetitif dengan kompetitor lainnya. memiliki nilai rata-rata tertinggi sebesar 3,99 yang masuk kedalam kriteria baik, hal ini berarti bahwa responden menganggap harga dari The Old Champ Cafe bersaing dengan cafe lainnya yang pernah dikunjungi responden. Nilai rata-rata terendah yaitu sebesar 3,86 yang termasuk dalam kriteria baik, harga yang ditawarkan The Old Champ Cafe sesuai dengan kualitas layanan yang diberikan, hal ini berarti responden mengakui bahwa pelayanan yang diberikan The Old Champ Cafe sesuai dengan harga yang ditawarkan. Jumlah skor rata-rata indikator secara keseluruhan sebesar 3,90 yang termasuk dalam kriteria baik.

Penilaian pada Tabel 9. responden terhadap setiap indikator dari variabel kepuasan pelanggan, dimana pernyataan saya merekomendasikan The Old Champ Cafe kepada pihak lain. memiliki nilai rata-rata tertinggi sebesar 4,14 yang masuk kedalam kriteria baik, hal ini berarti bahwa responden akan memberitahukan pengalaman baik saat berbelanja pada The Old Champ Cafe. Nilai rata-rata terendah yaitu sebesar 3,90 yang termasuk dalam kriteria baik ditunjukkan pada indikator dengan pernyataan bahwa Saya merasa bangga setelah melakukan pembelian pada The Old Champ Cafe, hal ini berarti responden mengakui bahwa mereka baangga setelah melakukan pembelian pada The Old Champ Cafe. Jumlah skor rata-rata indikator secara keseluruhan sebesar 3,99 yang termasuk dalam kriteria baik 
Tabel 9.

Penilaian Responden Terhadap Indikator Variabel Kepuasan Pelanggan

\begin{tabular}{|c|c|c|c|c|c|c|c|c|}
\hline \multirow{2}{*}{ No } & \multirow{2}{*}{ Pernyataan } & \multicolumn{5}{|c|}{ Skor Jawaban } & \multirow{2}{*}{$\begin{array}{l}\text { Rata- } \\
\text { Rata }\end{array}$} & \multirow{2}{*}{ Ket. } \\
\hline & & 1 & 2 & 3 & 4 & 5 & & \\
\hline 1 & $\begin{array}{l}\text { Saya merekomendasikan } \\
\text { The Old Champ Cafe } \\
\text { kepada pihak lain. }\end{array}$ & 0 & 2 & 18 & 42 & 36 & 4,14 & Baik \\
\hline 2 & $\begin{array}{l}\text { Saya akan melakukan } \\
\text { pembelian berulang } \\
\text { terhadap The Old Champ } \\
\text { Cafe. }\end{array}$ & 0 & 4 & 25 & 42 & 27 & 3,94 & Baik \\
\hline 3 & $\begin{array}{l}\text { Saya merasa bangga } \\
\text { setelah melakukan } \\
\text { pembelian pada The Old } \\
\text { Champ Cafe. } \\
\quad \text { Skor Rata-Rata Ve }\end{array}$ & 1 & 4 & 27 & 38 & 28 & 3,90 & Baik \\
\hline
\end{tabular}

Tabel 10.

Hasil Analisis Regresi Linier Berganda

\begin{tabular}{|c|c|c|c|c|c|}
\hline \multirow{2}{*}{ Model } & \multicolumn{2}{|c|}{$\begin{array}{c}\text { Unstandardized } \\
\text { Coefficients }\end{array}$} & \multirow{2}{*}{$\begin{array}{c}\begin{array}{c}\text { Standardized } \\
\text { Coefficients }\end{array} \\
\text { Beta } \\
\end{array}$} & \multirow{2}{*}{$\mathbf{T}$} & \multirow{2}{*}{ Sig. } \\
\hline & $\mathbf{B}$ & Std. Error & & & \\
\hline (Constant) & 0,059 & 0,290 & & 0,203 & 0,840 \\
\hline Kualitas Produk & 0,464 & 0,100 & 0,422 & 4,661 & 0,000 \\
\hline Kualitas Layanan & 0,304 & 0,123 & 0,271 & 2,483 & 0,015 \\
\hline Kewajaran Harga & 0,199 & 0,091 & 0,211 & 2,199 & 0,030 \\
\hline
\end{tabular}

Sumber: Data primer diolah, 2020

Nilai koefisien regresi Kualitas Produk $\left(\mathrm{X}_{1}\right)$ sebesar 0,422 memiliki arti Kualitas Produk berpengaruh positif terhadap Kepuasan Pelanggan (Y). Semakin baik kualitas produk The Old Champ Cafe maka kepuasan pelanggan akan meningkat. Dengan nilai signifikansi $X_{1}$ lebih kecil dari $0,05(0,000<0,05)$. Nilai koefisien regresi Kualitas Layanan $\left(\mathrm{X}_{2}\right)$ sebesar 0,271 memiliki arti Kualitas Layanan berpengaruh positif terhadap Kepuasan Pelanggan (Y). Semakin baik kualitas layanan The Old Champ Cafe maka kepuasan pelanggan akan meningkat. Dengan signifikasi $\mathrm{X}_{2}$ lebih kecil dari $0,05(0,015<0,05)$. Nilai Koefisien regresi Kewajaran Harga $\left(\mathrm{X}_{3}\right)$ sebesar 0,211 memiliki arti Kewajran Harga berpengaruh positif terhadap Kepuasan Pelanggan (Y). Semakin wajar harga yang ditawarkan The Old Champ Cafe maka kepuasan pelanggan akan meningkat. Dengan signifikansi $\mathrm{X}_{3}$ lebih kecil dari $0,05(0,030<0,05)$.

Tabel 11.

Hasil Uji Normalitas Persamaan Regresi

\begin{tabular}{ll}
\hline & Unstandardized Residual \\
\hline $\mathrm{N}$ & 98 \\
Kolmogorov-Smirnov $Z$ & 1,045 \\
Asymp. Sig. (2-tailed) & 0,225 \\
\hline Sumber: &
\end{tabular}

Sumber: Data primer diolah, 2020 
Tabel 11. terlihat bahwa nilai Kolmogorov-Smirnov (K-S) sebesar 1,045 dan nilai koefisien Asymp. Sig sebesar 0,225>0,05 sehingga model regresi dapat dinyatakan berdistribusi normal.

Tabel 12.

Hasil Uji Multikoleniaritas

\begin{tabular}{lll}
\hline Variabel & Tolerance & VIF \\
\hline Kualitas Produk $\left(\mathrm{X}_{1}\right)$ & 0,424 & 2,360 \\
Kualitas Layanan $\left(\mathrm{X}_{2}\right)$ & 0,292 & 3,425 \\
Kewajran Harga $\left(\mathrm{X}_{3}\right)$ & 0,376 & 2,656 \\
\hline Sumber:
\end{tabular}

Sumber: Data primer diolah, 2020

Tabel 12. dapat dilihat bahwa nilai tolerance dan VIF dari variabel kualitas produk, kualitas layanan, dan kewajaran harga menunjukkan nilai tolerance untuk setiap variabel kurang dari 10 yang berarti model regresi bebas multikoleniaritas.

Tabel 13.

Hasil Uji Heteroskedastisitas

\begin{tabular}{lll}
\hline \multicolumn{1}{c}{ Model } & T & Sig. \\
\hline Kualitas Produk & 1,224 & 0,224 \\
Word Of Mouth & 0,143 & 0,886 \\
Internet Marketing & $-1,312$ & 0,193 \\
\hline
\end{tabular}

Sumber: Data primer diolah, 2020

Tabel 13. menunjukan bahwa nilai Sig. dari variabel Kualitas Produk, Kualitas Layanan, dan Kewajran Harga lebih dari 0,05 yang artinya model regresi bebas dari gejala heteroskedastitas.

Tabel 14.

Hasil Analisis Koefisien Determinasi $\left(\mathbf{R}^{2}\right)$

\begin{tabular}{cccc}
\hline $\mathbf{R}$ & R Square & Adjusted R Square & $\begin{array}{c}\text { Std. Error of } \\
\text { Estimate }\end{array}$ \\
\hline $0,821^{\mathrm{a}}$ & 0,674 & 0,663 & 0,42342 \\
\hline
\end{tabular}

Sumber: Data primer diolah, 2020

Berdasarkan hasil uji pada Tabel 14. nilai R square sebesar 0,674. Sehingga dapat dihitung persentase kontribusi Kualitas Produk, Kualitas Layanan, dan Kewajaran Harga terhadap Kepuasan Pelanggan sebesar 0,674 x 100 persen =67,4 persen dan sisanya 32,6 persen dipengaruhi oleh variabel lain diluar penelitian.

Tabel 15.

Hasil Uji F (Uji Kelayakan Model)

\begin{tabular}{cccccc}
\hline Model & $\begin{array}{c}\text { Sum of } \\
\text { square }\end{array}$ & Df & Mean square & F & Sig. \\
\hline Regression & 34,822 & 3 & 11,607 & 64,743 & $0.000^{\mathrm{a}}$ \\
Residual & 16,853 & 94 & 0,179 & & \\
Total & 51,674 & 97 & & & \\
\hline
\end{tabular}

Sumber: Data primer diolah, 2020 
Tabel 15. menunjukan nilai sig sebesar 0,000 yang lebih kecil dari 0,05 (sig $<$ a) yang berarti variabel bebas yaitu Kualitas Produk $\left(X_{1}\right)$, Kualitas Layanan $\left(X_{2}\right)$, Kewajaran Harga $\left(\mathrm{X}_{3}\right)$ berpengaruh signifikan secara serempak atau bersama-sama terhadap variabel terikat yaitu Kewajaran Harga (Y), sehingga penelitian ini dapat dikatakan memenuhi uji kelayakan model atau model penelitian ini dinyatakan layak digunakan sebagai model regresi.

Pengaruh kualitas produk terhadap kepuasan pelanggan diperoleh nilai sig.t 0,000 dengan nilai koefisien beta 0,422 . Nilai Sig.t $0,000<0,05$ hasil ini menunjukan bahwa kualitas produk berpengaruh positif dan signifikan terhadap kepuasan pelanggan. Berarti apabila kualitas produk semakin baik maka kepuasan pelanggan akan meningkat. Hasil penelitian ini sesuai dengan Hipotesis satu $\left(\mathrm{H}_{1}\right)$ yang di ajukan dan diteliti dalam penelitian Hoe \& Mansori (2018) bahwa kualitas produk berpengaruh signifikan terhadap kepuasan pelanggan. Ismail \& Yunan (2016) menemukan bahwa peningkatan kualitas produk yang kompetitif dapat meningkatkan kepuasan pelanggan. Kualitas produk memiliki pengaruh positif terhadap kepuasan pelanggan dikemukakan pada penelitian yang dilakukan oleh Nuridin (2018)

Pengaruh kualitas layanan terhadap kepuasan pelanggan diperoleh nilai sig.t 0,015 dengan nilai koefisien beta 0,271. Nilai Sig.t $0,015<0,05$ hasil ini menunjukan bahwa kualitas layanan berpengaruh positif dan signifikan terhadap kepuasan pelanggan. Yang berarti apabila kualitas layanan semakin baik maka kepuasan pelanggan akan meningkat. Hasil penelitian ini sesuai dengan Hipotesis satu $\left(\mathrm{H}_{2}\right)$ yang di ajukan dan diteliti oleh Niaam \& Adhimmum (2016) didapatkan hasil bahwa kualitas layanan berpengaruh positif dan signifikan terhadap kepuasan pelanggan. Menurut penelitian yang telah dilakukan oleh Minh et al. (2015) memperlihatkan kualitas layanan memiliki pengaruh yang positif dan signifikan dengan kepuasan pelanggan

Pengaruh kewajaran harga terhadap kepuasan pelanggan diperoleh nilai sig.t 0,030 dengan nilai koefisien beta 0,211 . Nilai Sig.t $0,030<0,05$ hasil ini menunjukan bahwa kewajaran harga berpengaruh positif dan signifikan terhadap kepuasan pelanggan. Yang berarti apabila kewajaran harga semakin baik maka kepuasan pelanggan akan meningkat. Hasil penelitian ini sesuai dengan Hipotesis satu $\left(\mathrm{H}_{3}\right)$ yang di ajukan dan diteliti oleh Surip et al. (2017), menyatakan bahwa variabel harga berpengaruh signifikan terhadap kepuasan konsumen. Penelitian Ismail \& Yunan (2016) menemukan bahwa harga yang kompetitif dapat meningkatkan kepuasan pelanggan, hal ini juga didukung oleh studi dari Ehsani (2015), mereka mengatakan bahwa harga dapat meningkatkan kepuasan pelanggan.

Implikasi secara teoretis menunjukkan adanya penerapan teori-teori yang menjelaskan pengaruh dari variabel kualitas produk, kualitas layanan, dan kewajaran harga terhadap kepuasan pelanggan. Hasil penelitian ini juga memberikan dukungan empiris dan juga dapat memperkuat hasil-hasil dari studi terdahulu. Implikasi secara praktis dari hasil penelitian ini menekankan pada manfaat nyata untuk mendorong perusahaan-perusahaan yang baru berkembang dan khususnya bagi perusahaan yang telah memiliki penilaian yang positif di masyarakat. Hal ini menunjukkan bahwa pentingnya membangun citra produk 
yang baik agar konsumen percaya bahwa ketika kualitas yang baik mampu diinformasikan kepada konsumen akan menimpulkan rasa puas terhadap konsumen, sehingga dapat meningkatkan profit dan dapat mengembangkan usahanya.

Keterbatasan yang mempengaruhi dalam penelitian ini adalah Faktor-faktor yang mempengaruhi Keputusan Pembelian dalam penelitian ini hanya terdiri dari tiga variabel, yaitu Kualitas Produk, Kualitas Layanan, dan Kewajaran Harga Sedangkan masih banyak faktor lain yang mempengaruhi Kepuasan pelanggan. Sampel yang dijadikan responden hanya konsumen yang berdomisili di Kota Denpasar saja, sehingga kurang bisa mewakili penilian konsumen yang berkunjung terhadap The Old Champ Cafe dari luar Kota Denpasar. Penelitian ini yaitu dalam titik waktu tertentu sedangkan lingkungan bisa berubah kapanpun, dimana penelitian ini penting untuk dilakukan kembali.

\section{SIMPULAN}

Kualitas produk berpengaruh positif dan signifikan terhadap kepuasan pelanggan. Hal ini menunjukan bahwa semakin tinggi kualitas produk maka konsumen akan merasa lebih puas dengan produk yang ditawarkan. Kualitas layanan berpengaruh positif dan signifikan terhadap kepuasan pelanggan. Hal ini menunjukan bahwa semakin baik layanan yang diberikan maka kepuasan semakin meningkat. Kewajaran harga berpengaruh positif dan signifikan terhadap kepuasan pelanggan. Hal ini menunjukan bahwa semakin wajar harga yang diberikan maka kepuasan akan semakin meningkat.

Diharapkan dengan peningkatan kualitas produk seperti meningkatkan fitur tambahan pada The Old Champ Cafe akan meningkatkan jumlah konsumen sehingga The Old Champ Cafe dapat bersaing dan bisa mencapai tujuan serta mengalami perkembangan secara terus menerus. Kualitas layanan memiliki pengaruh yang luar biasa, jika hal ini dapat digunakan dengan sangat baik seperti meningkatkan pelayanan yang responsif dan memperhatikan konsumen ketika melakukan pembelian, maka The Old Champ Cafe dapat memuaskan konsumen sehingga konsumen terus melakukan pembelian, diharapkan The Old Champ Cafe memberikan kepercayaan dan rasa puas pada konsumen dengan ciri khas yang dimiliki The Old Champ Cafe. Kewajaran harga juga sangat penting dalam meningkatkan kepuasan pelanggan. Dimana harga sangat berpengaruh besar terhadap minat beli seseorang, sehingga perlu memperhatikan kewajaran harga yang pas di benak konsumen agar konsumen puas melakukan pembelian pada The Old Champ Cafe.

\section{REFERENSI}

Ackaradejruangsri, P. (2015). The Effect of Product Quality Attributes on Thai Consumers'Buying Decisions. Ritsumeikan Journal of Asia Pasific Studies, 33(1), 14-23.

Alfin, R. (2016). Mediation Effects on Customer Satisfaction and Service 
QualityProduct Quality of Customer Loyalty. Journal of Contemporery Researchin Business, 5(6), 735-745.

Ayuniah, P. (2017). Analisis Pengaruh Citra Merek, Kualitas Produk, Iklan, dan Harga terhadap Keputusan Pembelian Produk Kosmetik Wardah (Studi Kasus pada Mahasiswi Jurusan Manajemen Fakultas Ekonomi Universitas Gunadarma yang Mengambil Kuliah di Kampus Depok. Jurnal Ekonomi Bisnis, 22(3), 208-219.

Danish, R. Q., Himayon, A. A., Iqbal, H. J., Raza, S., \& Shahid, J. (2018). The Impact of Service Quality, Customer Satisfaction and Loyalty Programs on Customer's Loyalty: An Evidence from Telecommunication Sector. European Online Journal of Natural and Social Sciences, 7(1), 40-47. Retrieved from http:/europeanscience.com/eojnss_proc/article/view/5346/2518

Ehsani, Z. E. H. (2015). Effect of quality and price on customer satisfaction and commitment in Iran auto industry. International Journal of Service Science, Management and Engineering, 1(5), 52-56.

Ekawati, N. W. (2016). The Implementation of Ecopreneurship and Green Innovation in Building Competitive Advetage to Generate Succes of New Spa Products in Bali. International Business Management, 10(14), 2660-2669.

Gong, T., \& Yi, Y. (2018). The effect of service quality on customer satisfaction, loyalty, and happiness in five Asian countries. Psychology and Marketing, 35(6), 427-442. https://doi.org/10.1002/mar.21096

Gunawan, N. G., \& Chandra, K. (2018). Pengaruh Kualitas Pelayanan dan Lokasi Terhadap Kepuasan Pelanggan Pada Rolag Cafe Diponegoro Surabaya. Jurnal Ilmu Ekonomi \& Manajemen, 5(1), 13-23.

Henriawan, D. (2015). Pengaruh Kualitas Pelayanan dan Kepuasan Pelanggan Terhadap Loyalitas Pelanggan (Studi Kasus pada Toko Cabang Mufin Wilayah Bandung Timur). Universitas Sebelas Maret.

Hoe, L. C., \& Mansori, S. (2018). The Effects of Product Quality on Customer Satisfaction and Loyalty: Evidence from Malaysian Engineering Industry. International Journal of Industrial Marketing, 3(1), 20. https://doi.org/10.5296/ijim.v3i1.13959

Ismail, A., \& Yunan, Y. S. M. (2016). Service Quality As a Predictor of Customer Satisfaction and Customer Loyalty. Logforum, 12(4), 269-283. https://doi.org/10.17270/J.LOG.2016.4.7

Kristiana, M. K., \& Kastawan, M. (2019). Peran Kepuasan Pelanggan Dalam 
Memediasi Pengaruh Kualitas Pelayanan dan Kewajaran Harga Terhadap Loyalitas Pelanggan. E-Jurnal Manajemen, 8(2), 7576-7605.

Kurnia, D. (2016). Pengaruh Kualitas Produk Terhadap Loyalitas Nasabah Melalui Kepuasan Nasabah, Nilai Bagi Nasabah, dan Reputasi Perusahaan Pada Bank BUMN. UG Jurnal, 10(12), 5-8.

Mahmud, A., Kamaruzaman, J., \& Hadijah, S. (2015). The Effect of Service Quality and Price on Satisfaction and Loyalty of Customer of Commercial Flight Service Industry. World Applied Sciences Journal, 23(3), 354-359.

Minh, N. H., Thu Ha, N., Chi Anh, P., \& Matsui, Y. (2015). Service quality and customer satisfaction: A case study of hotel industry in Vietnam. Asian Social Science, 11(10), 73-85. https://doi.org/10.5539/ass.v11n10p73

Nguyen, M. T. (2015). Effects of Service Quality and Price Fairness on Student Satisfaction. International Journal of Business and Social Science, 3(19), $132-150$.

Niaam, \& Adhimmum. (2016). Kepuasan Memediasi Pengaruh Kualitas Produk dan Layanan Terhadap Loyalitas Nasabah. Jurnal Ilmu Dan Riset Manajemen, 5(2), 1-20.

Nuridin. (2018). Effect of Service Quality and Quality of Products to Customer loyalty with Customer Satisfaction as Intervening Variable in PT. Nano Coating Indonesia. International Journal of Business and Applied Social Science, 4(1), 19-31.

Nurmalasari, W., \& Jokom, R. (2016). Pengaruh Dimensi Kualitas Layanan Terhadap Kepuasan Konsumen Di Hotel Zoo Surabaya. Jurnal Manajemen Perhotelan, 1(2), 495-507.

Oosthuizen, \& Spowart. (2015). The Relationship Between Perceived Price and Consumers' Purchase Intentions of Private Label Wine Brands. African Journal of Hospitality, 4(2), 1-17.

Panjaitan, J. E., \& Yuliati, A. L. (2016). Pengaruh Kualitas Pelayanan terhadap Kepuasan Pelanggan pada JNE Cabang Bandung. DeReMa Jurnal Manajemen, 11(2), 1-20.

Putra, M. C. S. D. P., \& Ekawati, N. W. (2017). Pengaruh inovasi Produk Harga, Citra Merek dan Kualitas Pelayanan Terhadap Loyalitas Pelanggan Sepeda Motor Vespa. E-Jurnal Manajemen Unud, 6(3), 1674-1700.

Rahyuda, I. K., \& Atmaja, N. P. C. D. A. (2011). Pengaruh Kewajaran Harga, Citra Perusahaan Terhadap Kepuasan dan Loyalitas Pengguna Penerbangan 
Domestik GIA di Denpasar. Jurnal Ekonomi\& Keuangan, 15(3), 370 - 395.

Razak, I., \& Boge, T. (2016). The Impact Of Product Quality and Price on Customer Satisfaction With The Mediatorof Customer Value. .30,pp: . Journal of Marketing and Consumer Research, 30(1), 2422-8451.

Sanjaya, K. D. A. S., \& Ardani, I. G. A. (2018). Pengaruh Brand Image Dalam Memediasi Pengaruh Kualitas Produk Terhadap Niat Beli Ulang. E-Jurnal Manajemen Unud, 7(11), 6156-6183.

Siswanto, S., \& Widjaja, D. (2017). Pengaruh Kualitas Layanan terhadap Kepuasan Konsumen di PT. Daya Daihatsu Puri Kembangan. Jurnal Ilmiah Manajemen Bisnis, 17(2), 125-134.

Suariedewi, I. G. A. A. M., \& Sulistyawati, E. (2016). Peran Perceived Value dalam memediasi Kualitas Pelayanan terhadap Kepuasan Konsumen. E-Jurnal Manajemen Unud, 5(12), 8199-8226.

Sumertana, I. W. (2016). Pengaruh Kualitas Pelayanan terhadap Loyalitas Pelanggan dengan Kepuasan Pelanggan sebagai Variabel Intervening pada Water Park Seririt Singaraja tahun 2014-2015. Jurnal Program Studi Pendidikan Ekonomi, 7(2), 1-20.

Surip, N., Pawirosumarto, S., \& Liestijati, F. (2017). the Effect of Products, Price and Service Quality on Customer Satisfaction in "Rice for the Poors" Program. Russian Journal of Agricultural and Socio-Economic Sciences, 72(12), 6-18. https://doi.org/10.18551/rjoas.2017-12.01

Sutrisno, A., \& Andajani, E. (2019). The Effects of Service Quality on Customer Satisfaction and Loyalty in a Logistics Company. KnE Social Sciences, 1(1), $1-20$.

Wijaya, I. P. S. A., \& Nurcaya, I. N. (2017). Kepuasan Pelanggan Memediasi Kualitas Produk Dan Kewajaran Harga Terhadap Loyalitas Merek Mcdonalds Di Kota Denpasar. E-Jurnal Manajemen Unud, 3(6), 1-20. 